\section{Response to: 'Digital health: a new dimension in rheumatology patient care' by Kataria and Ravindran}

It was with great interest that I read the e-letter by Drs Kataria and Ravindran ${ }^{1}$ directed to a recent article of mine in the new Annals of the Rheumatic Diseases section 'Thinking the unthinkable.'. Their comments are much appreciated, especially since they re-emphasise the upcoming disruption in chronic diseases, but also outline the complexity that many tools will not yet be approved by regulatory authorities for use in daily routine care. Digital biomarkers will be important for the prediction of clinical outcomes, and they rightly point out that patterns arising from genome-wide association studies could be helpful in providing insights into disease pathology. They also allude to the important item of data protection, which has become even more important in Europe with the introduction of the New European General Data Protection Regulation, ${ }^{3}$ which strongly enforces patients' rights. Finally, they rightly emphasise the role of the human being in artificial intelligence algorithms to validate the findings of these novel approaches. In the future, we will have to leave the sometimes comfortable cocoon to step into the digital world—of course aiming for a better and more rapid patient care.

\section{Gerd R Burmester}

Correspondence to Dr Gerd R Burmester, Department of Rheumatology and Clinical Immunology, Charité University Hospital, Berlin 10117, Germany; gerd.burmester@charite.de
Correction notice This article has been corrected since it published Online First. Reference 1 has been corrected.

Handling editor Josef S Smolen

Competing interests None declared.

Patient consent Not required.

Provenance and peer review Commissioned; internally peer reviewed.

(c) Author(s) (or their employer(s)) 2019. No commercial re-use. See rights and permissions. Published by BMJ.

\section{Check for updates}

To cite Burmester GR. Ann Rheum Dis 2019;78:e104.

Received 24 July 2018

Accepted 24 July 2018

Published Online First 2 August 2018

\section{Linked}

http://dx.doi.org/10.1136/annrheumdis-2018-214146

Ann Rheum Dis 2019;78:e104. doi:10.1136/annrheumdis-2018-214154

\section{REFERENCES}

1 Ravindran V, Kataria S. Digital health in rheumatology. Ann Rheum Dis 2019;78:e103.

2 Burmester GR. Rheumatology 4.0: big data, wearables and diagnosis by computer. Ann Rheum Dis 2018:77:963-5.

3 European Commission. 2018 reform of EU data protection rules. 2018. https://ec. europa.eu/commission/priorities/justice-and-fundamental-rights/data-protection/2018reform-eu-data-protection-rules_en (accessed 24 Jul 2018). 